\title{
Charcoal Stratigraphies for Kaua'i and the Timing of Human Arrival ${ }^{1}$
}

\author{
Lida Pigott Burney ${ }^{2,3}$ and David A. Bumey ${ }^{3}$
}

\begin{abstract}
Evidence from microscopic charcoal particle stratigraphy is presented from nine locations distributed throughout Kaua $i$ in the Hawaiian Islands, including windward and leeward coastal sites and interior bogs at elevations ranging up to $1220 \mathrm{~m}$. The overall trends are comparable with those reported for other mesic tropical island areas lacking strong seasonality, beginning with a general dearth of charcoal in sediments that predate evidence for humans on the island, followed by an increase of an order of magnitude or more at a time that probably represents first human presence at the site. In most cases, this initial peak or plateau of increased charcoal from presumably anthropogenic sources is followed by a prehistoric decrease and a second peak after European contact. Charcoal evidence presented here suggests a human presence in leeward coastal areas beginning ca. $830 \pm 50$ yr B.P. (1050-1095, 1140-1280 cal yr A.D.). One windward site, Limahuli Bog, may show charcoal evidence for humans as early as $1470 \pm 60 \mathrm{yr}$ B.P. (440-670 cal yr A.D.), but resolution is poor in the upper part of that core. Charcoal and sedimentological evidence suggests that Hawaiians were constructing fishponds as early as about eight centuries ago and that the massive stoneworks forming the Alekoko or Menehune Fishpond, probably the largest prehistoric stone structure in the Hawaiian Islands, may have been completed by $580 \pm 30$ yr в.P. (1305-1420 cal yr A.D.). Charcoal peaks in prehuman times, particularly at $3800 \pm 40$ yr в.P. (4080-4290 cal yr в.P.), may be associated with prolonged drought conditions. Charcoal particles are virtually absent from the late Pleistocene sediments collected from interior bogs.
\end{abstract}

IN evaluating possible causes for late prehistoric extinctions on any given landmass, perhaps no single data point is more important than the inferred date of human arrival. Scientific controversies regarding this critical point in the Americas (Martin and Steadman 1999) and Australia (Flannery 1994) make it clear that this is no easy determination at the

${ }^{1}$ This research was supported by NOAA Human Dimensions of Global Change grant no. NA46GP0465, NSF grant DEB-9707260, National Geographic Society grant 7072-01, and funding from the Smithsonian Institution, Kaua'i Community College, Kīlauea Point Natural History Association, and the Faculty Research Grants and Faculty Fellowship programs of Fordham University. Manuscript accepted 27 June 2002.

2 The Louis Calder Center-Biological Field Station, P.O. Box 887, Armonk, NY 10504.

${ }^{3}$ Department of Biological Sciences, Fordham University, Bronx, New York 10458.

Pacific Science (2003), vol. 57, no. 2:211-226

(C) 2003 by University of Hawai'i Press

All rights reserved continental level. In contrast, studies from the large remote island of Madagascar (Burney 1999) definitively show human arrival ca. two millennia ago, with good agreement between independent data sets, but estimates derived by various methods for first human arrival in many other areas show large discrepancies.

For instance, estimates for human arrival in the Hawaiian Islands from various archaeological sites range from the first century B.c. (Beggerly 1990) to A.D. 800 (Athens 1997). Although adherents of both the "long chronology" and the "short chronology" continue to hold forth, newer interpretations of genealogical information and reexamination of earlier radiocarbon dates mostly support the shorter chronology (Masse and Tuggle 1998). It would clearly be useful to the testing of hypotheses for a human role in late prehistoric extinctions in the Hawaiian Islands (Olson and James 1982) to know more certainly when Polynesian settlement began in the mid-Pacific. Stratigraphic charcoal particle analysis is an approach to the question 
of when humans arrived that is independent of the site-discovery constraints inherent to conventional archaeology. Detecting a sudden, prolonged spike, generally better described as a plateau, of microscopic charcoal particles in sediments of lakes, bogs, and caves has been used effectively on many islands and some continental areas to elucidate human arrival (see Grayson 2001 for a recent summary).

Evidence for human activity from charcoal particles has been reported for high-elevation interior Maui (Burney et al. 1995) and several coastal sites on $\mathrm{O}^{\prime}$ ahu (summarized in Athens 1997). The former study showed that an active volcano, and possibly droughts, led intermittently to substantial Holocene charcoal deposition before humans, but that values were generally low in the late Holocene until European contact. This site is extremely remote on the upper flank of Haleakalā Volcano at $2270 \mathrm{~m}$. Along the coasts of O'ahu, Athens and his collaborators have found charcoal evidence for a human presence beginning ca. $800 \mathrm{cal}$ yr A.D., increasing until ca. $1200 \mathrm{cal}$ yr A.D., then decreasing to low levels until European arrival, which resulted in a second increase (Athens 1997).

Kirch (1985) summarized the earlier consensus among Hawaiian archaeologists that the wetter leeward valleys of the Hawaiian Islands would have been settled first, perhaps by A.D. 400 in his estimation (but there is currently disagreement on this-see Athens 1997). Kirch further speculated that, by ca. A.D. 1000 , the dryer leeward valleys of the Islands, presumably less desirable for the traditional Polynesian styles of wetland taro cultivation, would have begun to be settled, perhaps at least partially in response to population pressure.

If this scenario is true, the expectations in terms of a charcoal stratigraphy for a dry leeward site might be: (1) very low background levels of charcoal in times before human arrival, except in the vicinity of active volcanoes; (2) a large (e.g., one to three orders of magnitude) increase in microscopic charcoal with human settlement in the vicinity (i.e., perhaps within a few kilometers - see Burney 1987, Clark 1988, Burney et al. 1994) by ca.
1000 cal yr A.D.; (3) after one to a few centuries, a decrease in charcoal values, based on charcoal results from other islands, but not to the very low values typical of times before human arrival; and (4) a second peak of anthropogenic charcoal after European contact and through the subsequent two centuries.

We report here on nine sites, arrayed along the dry leeward south coast of Kaua' $i$, on the wetter windward north side, and at various elevations in the interior. Each has been cored or excavated for sedimentological analyses and ${ }^{14} \mathrm{C}$ dating (Burney 2002), and one, the caves and sinkhole at Māhā'ulepū on the south coast, has been studied in detail for a wide range of stratigraphic indicators of environmental change, including artifacts, bird bones, invertebrate shells, diatoms, pollen, and plant macrofossils (Burney et al. 2001).

\section{MATERIALS AND METHODS}

For coring and excavation methods employed, see Burney et al. (2001) and Burney (2002). Sediment subsamples of $0.5 \mathrm{ml}$ were processed for charcoal analysis using concentrated $\mathrm{HNO}_{3}$ to remove organic matter, as in Swain (1973). Hydrofluoric acid was used to remove clay and sand, and microslides were prepared from this residue. Samples were spiked with a known quantity of Lycopodium spores and counted in liquid-glycerine mounts at $400 \times$ using a $10-\mu \mathrm{m}$ grid reticle. As in previous studies (e.g., Burney 1987, 1993, Burney et al. 1994), microscopic pieces were classified as "graminoid" (recognizable as derived from cuticles of grasses and sedges) or "other" (mostly wood and dicot leaf material, often amorphous). The projected area of each piece on the microslide was measured by counting grid squares and placed in size categories of $0.5-1,1-2,2-4,4-8,8-16$, $16-32,32-64,64-128$, and $>128$ squares. These data can then be converted to $\mu \mathrm{m}^{2} /$ $\mathrm{cm}^{3}$ of raw sediment as in most stratigraphic charcoal particle studies (e.g., Swain 1973, Paterson et al. 1987). Pieces in the entire subsample residue larger than $275 \mu \mathrm{m}$ in the smallest dimension are caught on a sieve of that mesh size after chemical treatment, so 


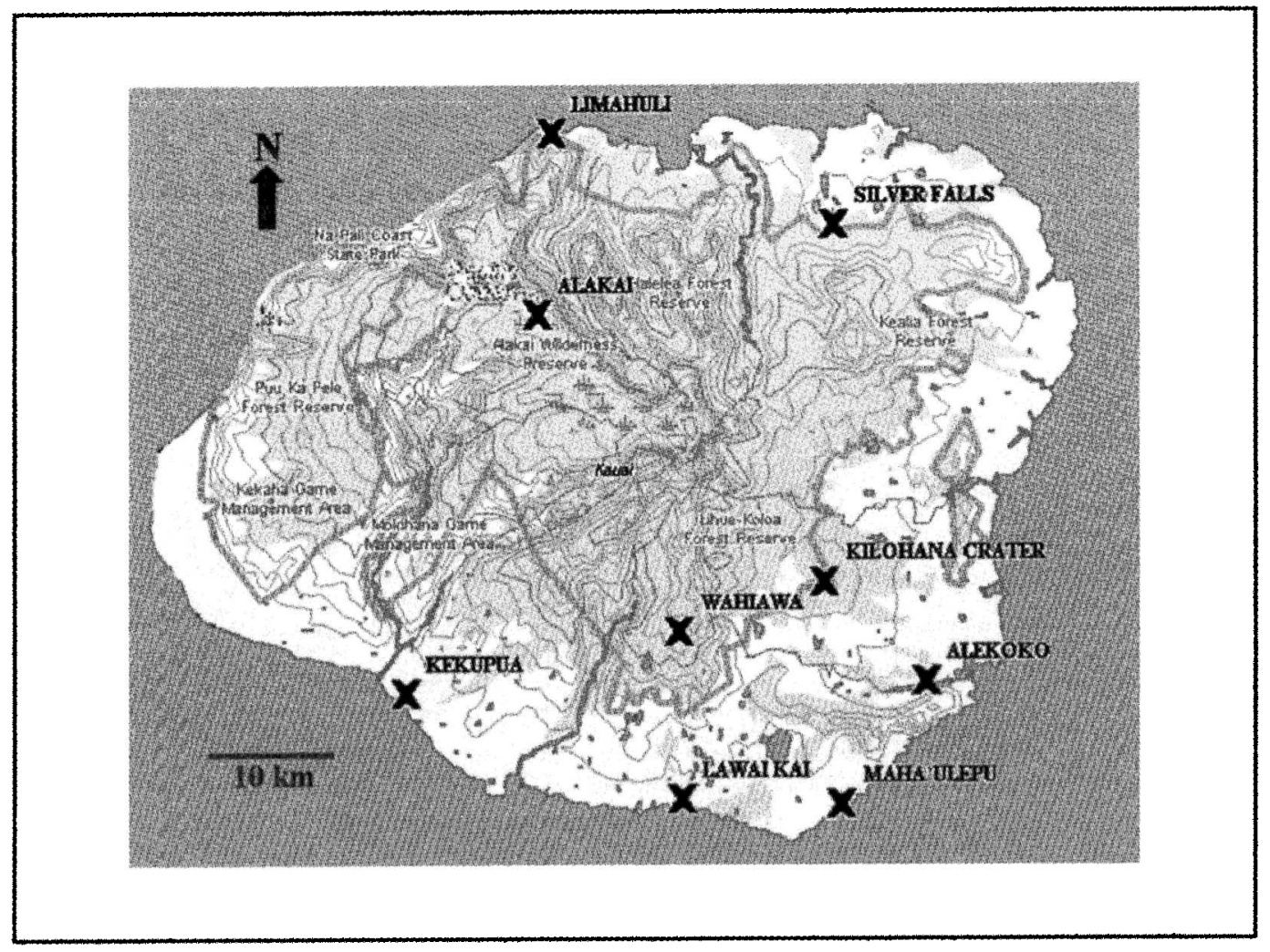

Figure 1. Location of sites on Kaua'i used for charcoal particle stratigraphy analysis.

they are individually counted, measured, and shown separately on the diagrams as "macroscopic charcoal." Microscopic charcoal particles, depending on size distribution in the sample and taphonomic processes (Clark 1988), are likely to be derived from regional, extralocal, and local fires. Macroscopic charcoal is almost exclusively derived from local sources.

In cores that showed sedimentological evidence for good temporal resolution in the late Holocene (e.g., preservation of fine-scale sediment structures) an effort was made to obtain ${ }^{14} \mathrm{C}$ dates on the level at which charcoal first shows a large increase that is likely to be an anthropogenic signal. Wherever possible, plant macrofossils were used for this dating. They were treated with hot $\mathrm{HCl}$ to remove carbonates, followed by $\mathrm{NaOH}$ to remove secondary organic acids, and a second $\mathrm{HCl}$ treatment. If a plant macrofossil was not available, bulk sediments were picked for rootlets and given the same pretreatments. This is the "humin" fraction, primarily pollen, spores, charcoal, and plant fibers. All dates are corrected for isotopic fractionation and reported in radiocarbon years before present $\pm 1 \sigma$ (yr B.P.), followed by the calibrated range at $2 \sigma$ (cal yr B.P. or cal yr A.D.), based on INTCAL98 (Stuiver et al. 1998).

\section{RESULTS AND DISCUSSION}

Figure 1 shows the location of each site. Table 1 contains additional information about each location. Sites analyzed for charcoal include estuaries from the dry $(\leq 1300$ $\mathrm{mm} / \mathrm{yr}$ ) leeward southern coast and the wet $(1600-2000 \mathrm{~mm} / \mathrm{yr})$ windward northern coast. Interior peat bogs and a crater swamp provide information on sites ranging from 169 to $1220 \mathrm{~m}$ in elevation. Increasing site 
TABLE 1

Sites for Stratigraphic Charcoal Particle Analysis from Kaua $i$

\begin{tabular}{|c|c|c|}
\hline Site & Latitude/Longitude/Elevation/Type & $\begin{array}{l}\text { Summary of Charcoal Particle Record and Key } \\
{ }^{14} \text { C Dates" }\end{array}$ \\
\hline Māhā'ulepū Caves & $\begin{array}{l}21^{\circ} 53^{\prime} 30^{\prime \prime} \mathrm{N} / 159^{\circ} 25^{\prime} 17^{\prime \prime} \mathrm{W} \\
2 \mathrm{~m} \\
\text { Cave system/paleolake }\end{array}$ & $\begin{array}{l}\text { Cores and excavations span the entire Holocene. } \\
\text { Charcoal scarce in the prehuman Holocene, } \\
\text { except at ca. } 3800 \pm 40 \text { yr B.P. }(4080-4290 \text { cal } \\
\text { yr в.P.). First evidence for humans at } 822 \pm 60 \\
\text { yr B.P. (1039-1241 cal yr A.D.). Large increase } \\
400 \text { yr B.P., then declines, increases again in } \\
\text { twentieth century. }\end{array}$ \\
\hline Alekoko Fishpond & $\begin{array}{l}21^{\circ} 57^{\prime} 07^{\prime \prime} \mathrm{N} / 159^{\circ} 22^{\prime} 34^{\prime \prime} \mathrm{W} \\
0 \mathrm{~m} \\
\text { Prehistoric fishpond/estuary }\end{array}$ & $\begin{array}{l}\text { Core begins at ca. } 3200 \mathrm{yr} \text { B.P. Charcoal } \\
\text { increases markedly at } 580 \pm 30 \text { yr B.P. (1305- } \\
1420 \text { cal yr A.D.), when sedimentological } \\
\text { evidence indicates pond construction. After } \\
\text { that time, decreases until nineteenth century. }\end{array}$ \\
\hline Kekupua Fishpond & $\begin{array}{l}21^{\circ} 56^{\prime} 46^{\prime \prime} \mathrm{N} / 159^{\circ} 39^{\prime} 14^{\prime \prime} \mathrm{W} \\
2 \mathrm{~m} \\
\text { Prehistoric fishpond }\end{array}$ & $\begin{array}{l}\text { Organic sedimentation begins ca. one millennium } \\
\text { ago. At } 830 \pm 50 \text { yr B.P. (1050-1095, } 1140- \\
1280 \text { cal yr A.D.), large charcoal increase noted. } \\
\text { Charcoal decreases over subsequent centuries. }\end{array}$ \\
\hline Lāwa'i Kai Fishpond & $\begin{array}{l}21^{\circ} 53^{\prime} 35^{\prime \prime} \mathrm{N} / 159^{\circ} 30^{\prime} 26^{\prime \prime} \mathrm{W} \\
1 \mathrm{~m} \\
\text { Prehistoric fishpond/estuary }\end{array}$ & $\begin{array}{l}\text { Estuary forms ca. } 6000-7000 \text { cal yr в.p. Charcoal } \\
\text { very scarce from that time until level reached } \\
\text { to which dredging was maintained. Pond filled } \\
\text { in by marine sediments in twentieth century. }\end{array}$ \\
\hline Limahuli Bog & $\begin{array}{l}22^{\circ} 13^{\prime} 31^{\prime \prime} \mathrm{N} / 159^{\circ} 34^{\prime} 37^{\prime \prime} \mathrm{W} \\
2 \mathrm{~m} \\
\text { Flood plain }\end{array}$ & $\begin{array}{l}\text { Throughout prehuman Holocene, charcoal is } \\
\text { very scarce except ca. } 3800 \text { yr в.P. Disturbed } \\
\text { layer above contains much charcoal; wood } \\
\text { dates to } 1470 \pm 60 \text { yr B.P. }(440-670 \text { cal yr } \\
\text { A.D.); sediment to } 1780 \pm 40 \text { yr B.P. (130-370 } \\
\text { cal yr A.D.). }\end{array}$ \\
\hline Silver Falls & $\begin{array}{l}22^{\circ} 10^{\prime} 37^{\prime \prime} \mathrm{N} / 159^{\circ} 25^{\prime} 21^{\prime \prime} \mathrm{W} \\
169 \mathrm{~m} \\
\text { Montane bog }\end{array}$ & $\begin{array}{l}\text { Charcoal scarce and intermittent in Holocene, } \\
\text { increases near bog surface. }\end{array}$ \\
\hline Kilohana Crater & $\begin{array}{l}22^{\circ} 00^{\prime} 02^{\prime \prime} \mathrm{N} / 159^{\circ} 25^{\prime} 42^{\prime \prime} \mathrm{W} \\
243 \mathrm{~m} \\
\text { Crater swamp }\end{array}$ & $\begin{array}{l}\text { Charcoal very scarce in late Pleistocene and } \\
\text { Holocene, increases near swamp surface. }\end{array}$ \\
\hline Wahiawā Bog & $\begin{array}{l}21^{\circ} 58^{\prime} 35^{\prime \prime} \mathrm{N} / 159^{\circ} 30^{\prime} 35^{\prime \prime} \mathrm{W} \\
665 \mathrm{~m} \\
\text { Montane bog }\end{array}$ & $\begin{array}{l}\text { Charcoal very scarce in late Pleistocene and } \\
\text { Holocene, except at layer dated to } 3800 \text { yr B.P. } \\
\text { No increase near bog surface. }\end{array}$ \\
\hline Alaka'i Swamp & $\begin{array}{l}22^{\circ} 09^{\prime} 28^{\prime \prime} \mathrm{N} / 159^{\circ} 35^{\prime} 56^{\prime \prime} \mathrm{W} \\
1220 \mathrm{~m} \\
\text { Montane bog }\end{array}$ & $\begin{array}{l}\text { Charcoal very scarce in late Pleistocene and } \\
\text { Holocene. No increase near bog surface. }\end{array}$ \\
\hline
\end{tabular}

“Dates given in radiocarbon years (yr B.P.) $\pm 1 \sigma$, followed by calibrated range at $2 \sigma$ (cal yr B.P. or A.D.). Calibrations, where available, from Stuiver et al. (1998).

"Sites designated "prehistoric fishpond/estuary" appear from sedimentary and geomorphological contexts to be natural estuaries modified by humans.

elevation correlates with increasing isolation from the coastal lowlands, where human population is concentrated today and presumably in prehistoric times as well (Kirch 1985). The interior sites all receive more rainfall than the leeward lowlands. It is likely that all of the coastal sites were utilized for prehistoric aquaculture, and this is confirmed for all but Limahuli Bog (Burney 2002).

\section{Māhā'ulepū Cave System}

Five years of work by a multidisciplinary team of scientists has produced a monograph (Burney et al. 2001) on the sinkhole paleolake site at Māhā'ulepū on the leeward south coast. Results from land snails, bird bones, pollen, plant macrofossils, and artifacts show stratigraphic evidence for human occupation 
in the vicinity in late prehistoric times. The oldest dated evidence for a human presence is an accelerator mass spectrometry determination on the gelatin fraction from the pelvis of the Polynesian-introduced Pacific rat (Rattus exulans) at $822 \pm 60 \mathrm{yr}$ в.P. $(1039-1241 \mathrm{cal} \mathrm{yr}$ A.D.), from a depth of $305-315 \mathrm{~cm}$ below surface and below datum in the lake sediments.

Unfortunately, sediments around this level are highly disturbed by an inferred tsunami event that occurred at the site ca. 400 yr B.P. (Burney et al. 2001). In any case, a large increase of charcoal particle deposition occurs in the cores and excavations in the site from ca. $400 \mathrm{yr}$ B.P. (i.e., as soon as normal sedimentation resumes after the tsunami [Figure 2]). Thus it is not feasible to conclude from the charcoal stratigraphy at this site that there was a local human presence in the vicinity before ca. four centuries ago, although the presence of the Pacific rat eight centuries ago confirms that people were on the island.

The sediments in this site are virtually charcoal-free in the levels predating the beginning of the second millennium A.D., with a notable exception. Core 6 , which is the most complete Holocene section from the site, is a $9.5-\mathrm{m}$ piston core from near the center of the paleolake. In this core, there is a very distinctive prehuman charcoal peak that begins at ca. $475 \mathrm{~cm}$ below surface $(560 \mathrm{~cm}$ below datum) and continues up through about 50 $\mathrm{cm}$ of sediment. This plateau, composed of roughly one-third graminoid charcoal, begins about $3800 \pm 40$ yr в.P. $(4290-4080 \mathrm{cal}$ yr в.P.). It is not surprising that the other two cores from the site analyzed for charcoal failed to detect this event, because sedimentological evidence suggests that only the center of the lake, in the vicinity of the core 6 location, was receiving sediment at that time, probably as a result of low-water conditions. The pollen evidence from the core (Burney et al. 2001) also indicated aridification at that time. Athens (1997) noted prehuman pollen evidence for aridity on $\mathrm{O}^{6}$ ahu in the mid- to late Holocene.

Charcoal also reaches a high level at $725 \mathrm{~cm}$ below surface in core 6 and moderate levels intermittently between these two spikes. The source of this charcoal is un- known, but the presence of particles in the larger size classes, including macroscopic charcoal, indicates that the source was probably on Kaua'i rather than, for instance, a major volcanic eruption on Maui or the Big Island of Hawai'i, 200-400 km leeward of Kaua'i.

\section{Alekoko (Menebune) Fisbpond}

A registered National Historical Landmark, the fishpond originally known as Alekoko (commonly referred to as the Menehune Fishpond in tourist guidebooks) is ideally situated to provide information regarding changes in the lowlands of the southeastern corner of Kaua' $i$. Its aspect is transitional between windward and leeward, with mean annual precipitation of ca. $1300 \mathrm{~mm}$. It is a place of great traditional, archaeological, and historical interest as one of the finest examples in the entire archipelago of prehistoric stonework and fishpond construction (Kikuchi 1976). Said to have been built overnight by the legendary menebune, it has also been suggested that this pond was built in the nineteenth century by Chinese plantation laborers. Early historical records and photos show that the pond predates the arrival of Chinese laborers (Ching et al. 1973). The current consensus among archaeologists is that most fishponds in the Hawaiian Islands were built by Polynesians well before European contact to practice advanced aquaculture and wetland agriculture (Kikuchi 1976, Kirch 1985).

A 4-m core collected from the pond (Burney 2002) showed that the estuary has deposited sediments there at least since $3230 \pm 70$ yr в.P. $(3620-3340 \mathrm{cal}$ yr в.P.). A unique layer of woody detritus marks a fundamental change to finer sediments at $580 \pm$ 30 yr B.P. (1305-1420 cal yr A.D.). Charcoal particles begin increasing ca. $15 \mathrm{~cm}$ below the woody layer. This material lacks a graminoid component (Figure 3). At and above the woody detritus layer, both graminoid and other charcoal reach values more than 10 times any previous value in the core. This increase is followed, after ca. $20 \mathrm{~cm}$ of charcoal-laden sediment, with a marked de- 

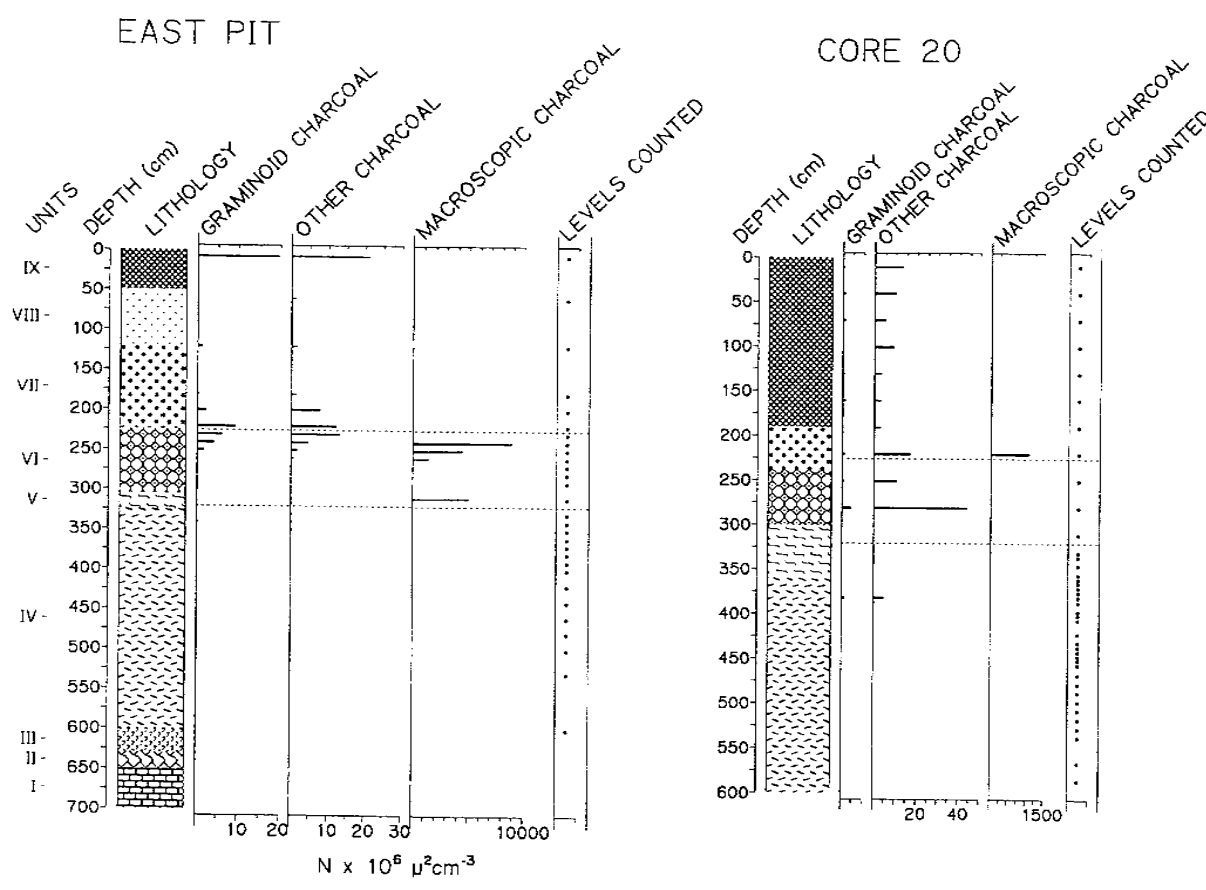
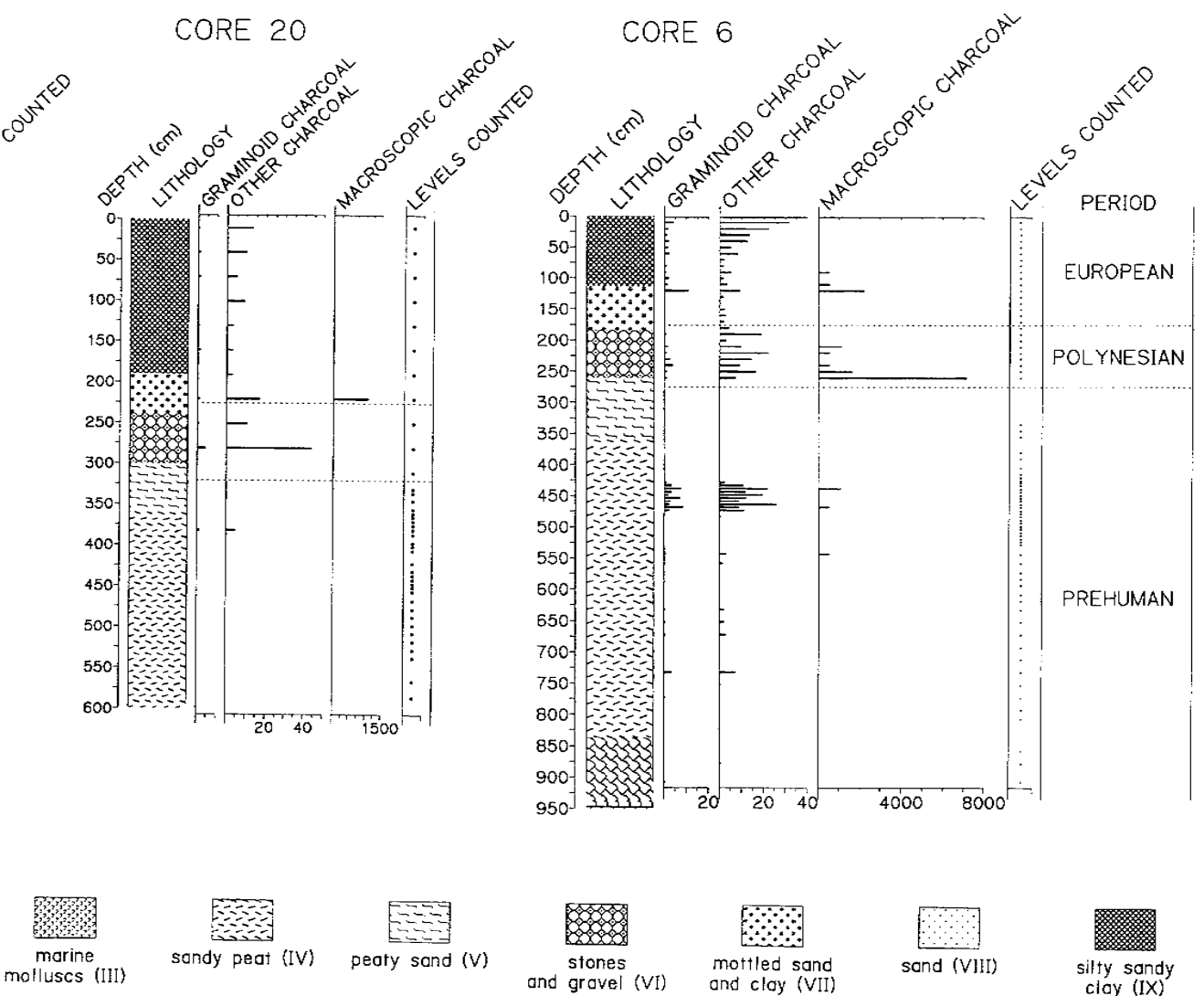

FIGURE 2. Three charcoal profiles from the sinkhole paleolake in the Māhā'ulepū Cave system on the south coast of Kaua'i. The East Pit profile is from the easter edge of the sinkhole; core 20 is from near the northern edge; core 6 is at the approximate geographic center of the sinkhole. Roman numerals in first column indicate stratigraphic units: (I) a previous interglacial; (II) ca. $9500 \mathrm{cal}$ yr B.P.; (III) ca. $7000 \mathrm{cal}$ yr B.P.; (IV) mid- to late Holocene; (V) late Holocene; (VI) $1430-1665 \mathrm{cal}$ yr A.D.; (VII) late eighteenth century to nineteenth century; (VIII) nineteenth to early twentieth century; (IX) mid-twentieth century to present. See Burney et al. (2001)
and Burney (2002) for dating basis. 


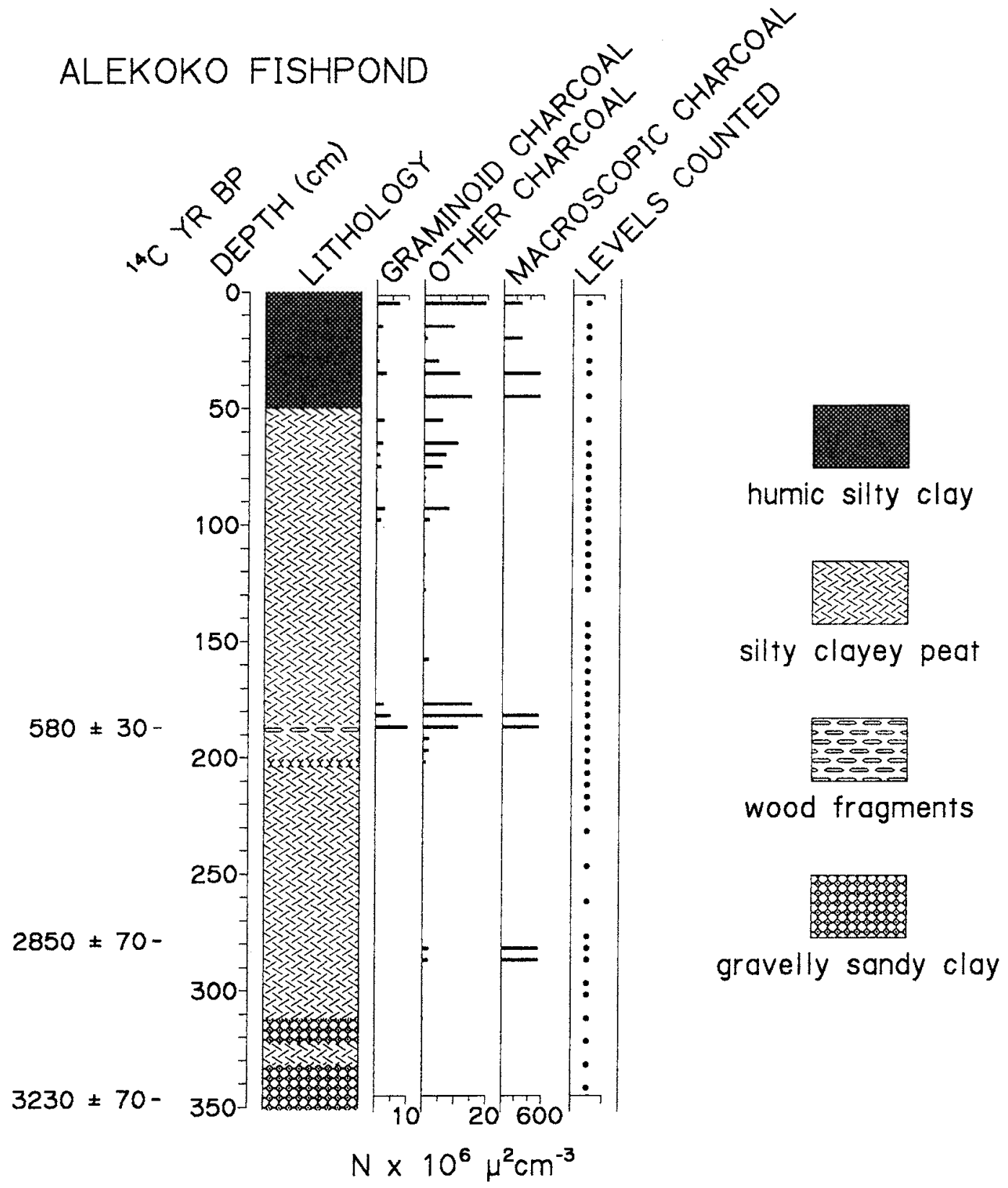

Figure 3. Charcoal stratigraphy from the Alekoko (Menehune) Fishpond near Lihu'e on the southeastern coast of Kaua'i.

crease to levels slightly above the background values in previous millennia. Charcoal particles increase again in sediments of the uppermost meter of the core, inferred to be post-European contact from sedimentary characteristics (Burney 2002).

We interpret this charcoal record to suggest that human settlement at the site extends 
back at least seven centuries and that during much of the last few centuries of Polynesian occupation before the arrival of Captain Cook in 1778 , relatively little burning of grass or trees occurred in the immediate vicinity. It is not known whether this is because the land nearby was nearly all covered with intensive agricultural and residential use soon after the fishpond was constructed or because of some inherent tendency of fire-ravaged landscapes to generate less charcoal over time after initial human settlement (see Burney et al. 1994 for a discussion of this pattern in the West Indies, Burney 1996 for Madagascar).

\section{Kekupua Fisbpond}

Between Makaweli and Waimea on the southwestern coast of Kaua' $i$ there is a small, shallow body of fresh water at the Kapalawai location known as the Kekupua Fishpond, said to be a prehistorically constructed, spring-fed reservoir. Four cores have been collected from the pond. The longest of these has been dated and described (Burney 2002).

This $220-\mathrm{cm}$ core contains a record of ca. one millennium. At $170 \mathrm{~cm}$, a level dated to $980 \pm 80$ yr B.P. $(895-1225$ cal yr A.D.) on a fruit of bala or screw pine (Pandanus tectorius), soft sediments overlie gravel. These sediments are low in charcoal particles (Figure 4). At $140 \mathrm{~cm}$, dated on the humin fraction of bulk sediments to $830 \pm 50$ yr B.P. (1050$1095,1140-1280$ cal yr A.D.) both graminoid and other charcoal levels are quite high, and this sediment is interpreted as the beginning of deposition after the pond was constructed (Burney 2002). Low to moderate charcoal levels have been recorded in the sediments between $105 \mathrm{~cm}$ and the surface.

Although the inferred date for initial fishpond construction is surprisingly early, this is the most parsimonious explanation for the change in sedimentation regime at that time, from coarse clastics to fine organic detritus. Although the difficulties of dating the pond's establishment are acknowledged in Burney (2002), firmer conclusions await completion of studies of additional cores taken from the site. To date, no oral traditions have been recorded in the vicinity that provide precise clues to the age of the pond, beyond confirming that it long predates European contact.

\section{Lāwa'i Kai}

At Läwa'i Kai, roughly midway between Māhā'ulepū and Kekupua Fishpond on the south coast (Figure 1), there is another fishpond believed to have been constructed in prehistoric times. This is a small natural estuary on the property of the National Tropical Botanical Garden that has been impounded by stone walls and packed earth along its west side to form a fishpond now entirely filled with marine sediments deposited by historically known tsunamis and hurricanes (Burney 2002). The longer of two cores collected from the site was a $654-\mathrm{cm}$ record that shows a good stratigraphic crosscorrelation with the Māhā'ulepū sedimentary record (Burney et al. 2001, Burney 2002). In both sites, sea level approached the base level of the basin (ca. $5 \mathrm{~m}$ below current sea level) ca. 6000-7000 cal yr B.P. Brackish or freshwater ponding followed, with an accumulation of fine sediments interrupted by periodic coarse-clastic influx that may represent hurricanes or tsunamis. The natural sedimentary record at Lāwa'i Kai appears to be truncated, perhaps by dredging, at ca. $180 \mathrm{~cm}$ below surface. At that level, large amounts of "other" charcoal and a trace of graminoids appear for the first time in the record (Figure 5). Above that level, the sediments are marine in origin, probably deposited by the 1946 tsunami and Hurricanes 'Twa (1982) and 'Iniki (1992). This reconstruction is consistent with local accounts (R. Gage, pers. comm., 1998) that the pond was maintained by dredging at a sufficient depth to raise mullet (Mugil cepbalus) and perhaps other fish until the site was devastated by the 1946 tsunami overwash and further choked with sediments from the two hurricane storm surges.

\section{Limabuli Bog}

There is a small fenlike wetland seaward of the entrance to Limahuli Gardens on Kaua 'i’s 


\section{KEKUPUA FISHPOND}

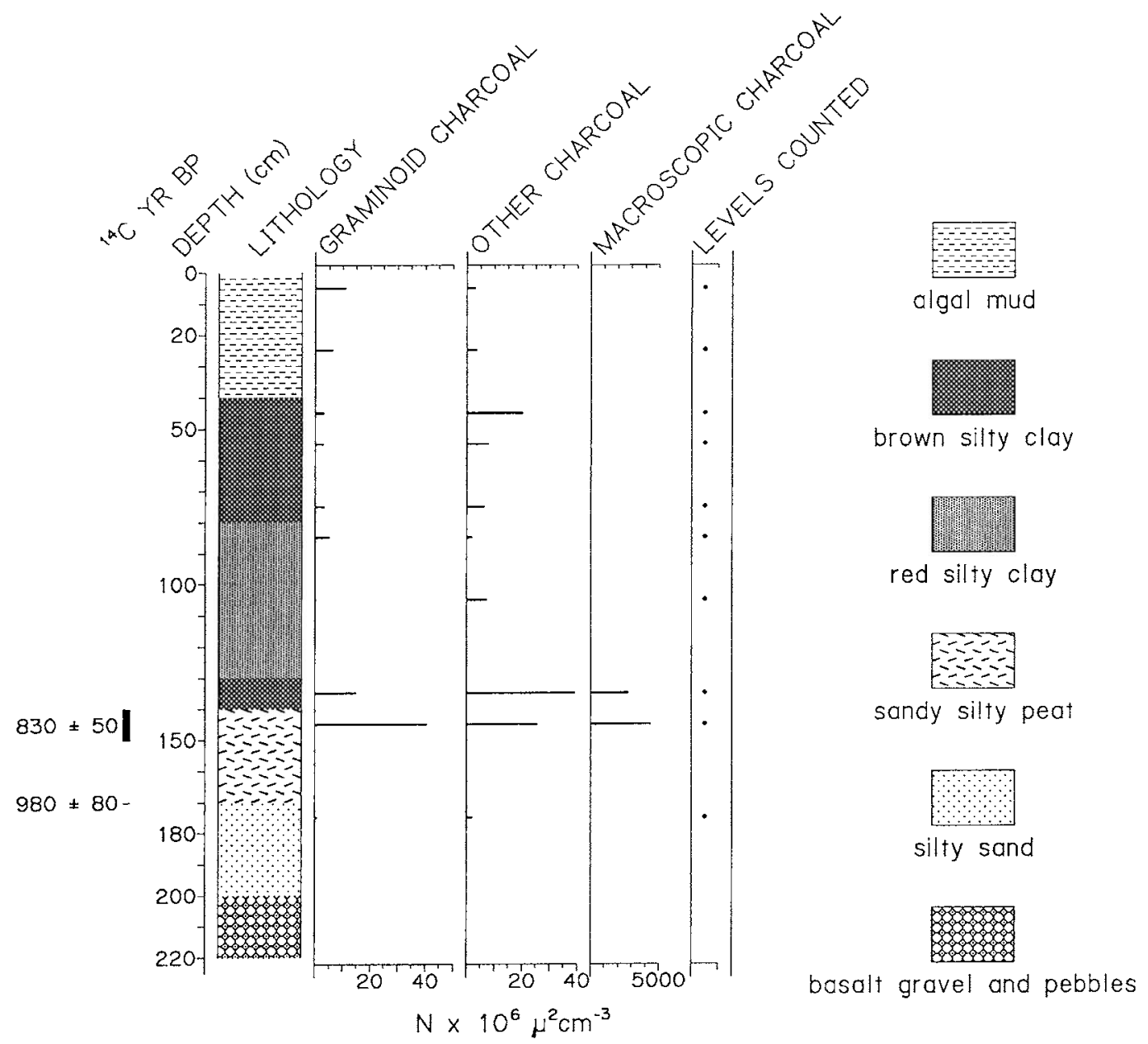

Figure 4. Charcoal stratigraphy from Kekupua Fishpond near Makaweli on the southwestern coast of Kaua'i.

north shore (Figure 1) that has received terrestrial sediments at least intermittently throughout the Holocene (Burney 2002). A 6-m core from the site contains very little charcoal until a point $15 \mathrm{~cm}$ above a level dated $3910 \pm 60$ yr B.P. $(4515-4465,4450-$ 4155 cal yr B.P.). A dense layer of wood prevented sediment recovery in much of late prehuman times, until a disturbed layer is reached in which large tree trunks are mixed with coarse and fine sediments (Figure 6). At that level, a piece of the outermost $2 \mathrm{~cm}$ of a buried $\log$ yielded an age of $1470 \pm 60 \mathrm{yr}$ B.P.
(440-670 cal yr A.D.). Sediments above this wood show a large (10 times) increase in charcoal. A bulk date on the humin fraction of associated sediments from a depth of 229$230 \mathrm{~cm}$ was $1780 \pm 40 \mathrm{yr}$ B.P. $(130-370 \mathrm{cal} \mathrm{yr}$ A.D.). It is unfortunate that the sediments in this key part of the record are disturbed (possibly by a prehistoric tsunami-see Burney 2002). The charcoal plateau in this core is not firmly dated, but it raises the possibility that settlement on the wet northern coast predates the south coast settlements by $\mathrm{ca}$. five centuries. 

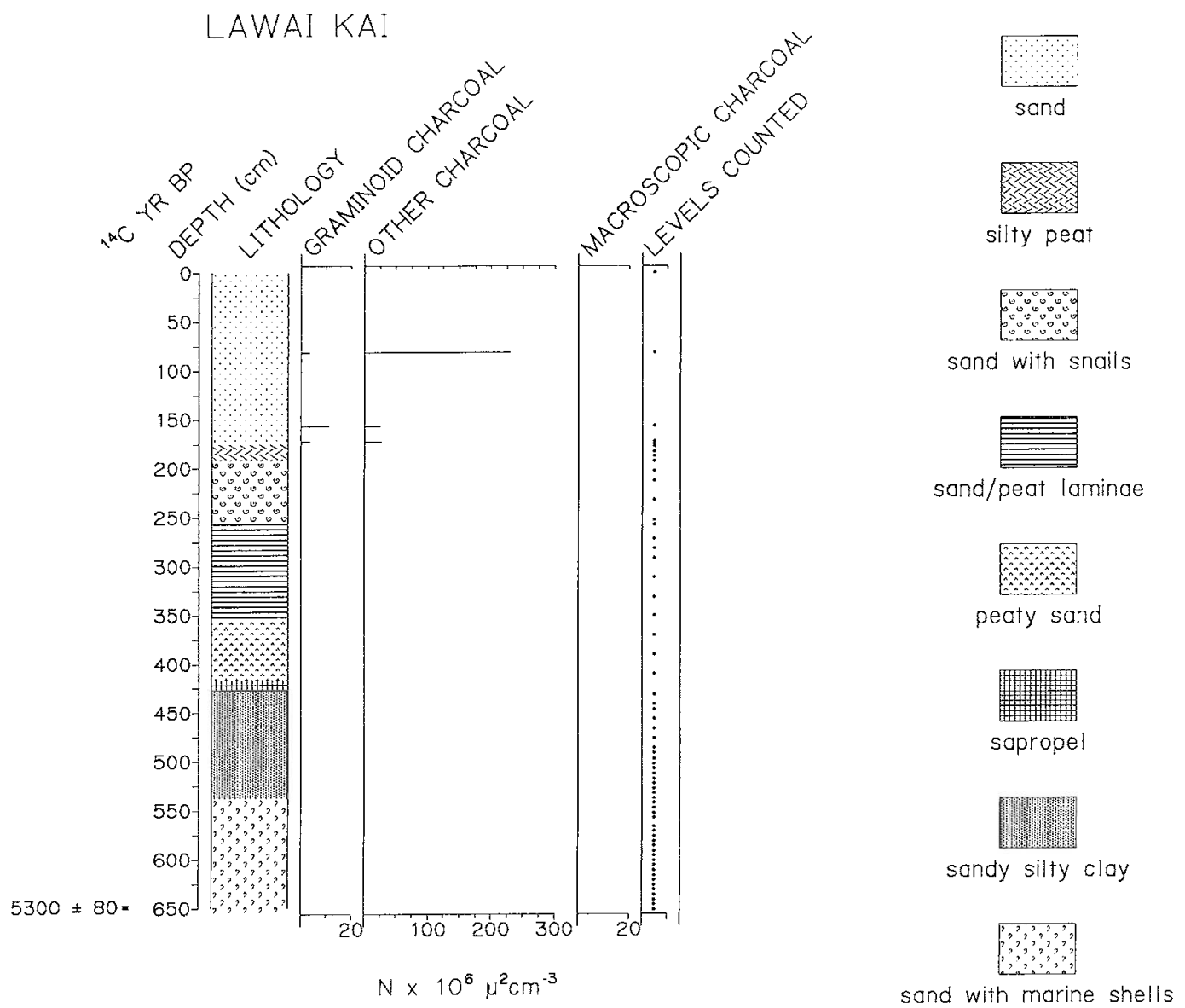

FIGURE 5. Charcoal stratigraphy from the prehistoric fishpond at Lāwa'i Kai, on the south central coast of Kaua'i.

\section{Silver Falls}

Also on the north side of the island is a site that is the lowest in elevation of the interior bogs examined. This interfluvial swamp is located inshore from the Kilauea Point area at an elevation of $169 \mathrm{~m}$ (Figure 1). A $3.5-\mathrm{m}$ record from the two adjacent cores collected at this site begins at a level dated on the humin fraction of bulk sediments to $8160 \pm 40$ yr в.P. (Figure 7). The sediments mostly consist of clays laid down during the subsequent approximately two millennia of the early Holocene. At a level interpolated to ca. seven millennia ago, there is a small peak of "other" charcoal. Charcoal appears again at ca. $70 \mathrm{~cm}$ below surface, but no large accu- mulation was detected. Dating of this layer was not attempted because of the abundance of fresh roots down to this zone and the lack of plant macrofossils in the sandy silty clay. Charred logs are present on and near the surface, evidence for twentieth-century fires remembered by elderly people in the area (U. Ratchener, pers. comm., 1999).

\section{Kilobana Crater}

The heavy clays on the floor of the large swamp forest at the bottom of Kilohana Crater in Kaua'i's southeastern interior (Figure 1) are underlain by layers of peaty sediments from the late Pleistocene. Coarse peat from 

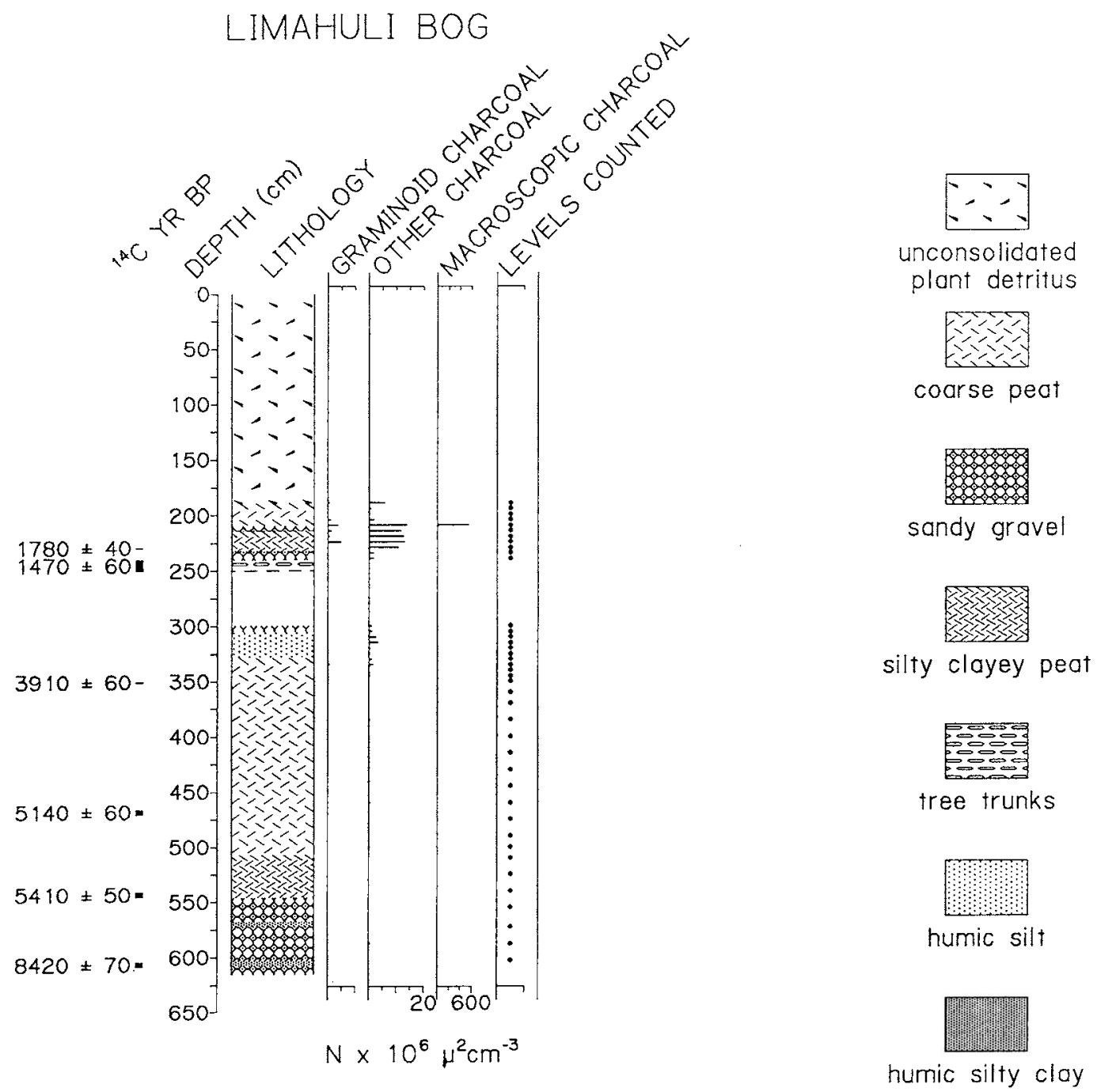

FIGURE 6. Charcoal stratigraphy from a bog on the north coast of Kaua'i at Limahuli Gardens. White space in the lithology diagram indicates a gap in core recovery due to woody nature of the layer.

$170 \mathrm{~cm}$ below surface in a $3-\mathrm{m}$ profile yielded $26,020 \pm 230$ yr B.P. (Figure 8 ).

Resolution of Holocene events at this site is poor, as in some other interior bogs of the archipelago (e.g., Hotchkiss 1998). It should be noted, however, that charcoal particles are essentially absent from the late Pleistocene sediments and only begin to appear ca. $25 \mathrm{~cm}$ below the surface, in the humic silty clay that forms the uppermost sedimentary unit.

\section{Wabiazvā Bog}

Also known as Kanaele Swamp, Wahiawā Bog is a large, remote montane bog in the south central interior of the island at $665 \mathrm{~m}$ (Figure 1). A 4.9-m core obtained here (Burney 2002) yielded a basal age of $23,090 \pm 180$ yr B.P. from the humin fraction of bulk sediment (Figure 9). It is not clear why the two Holocene dates near the top of the core are 


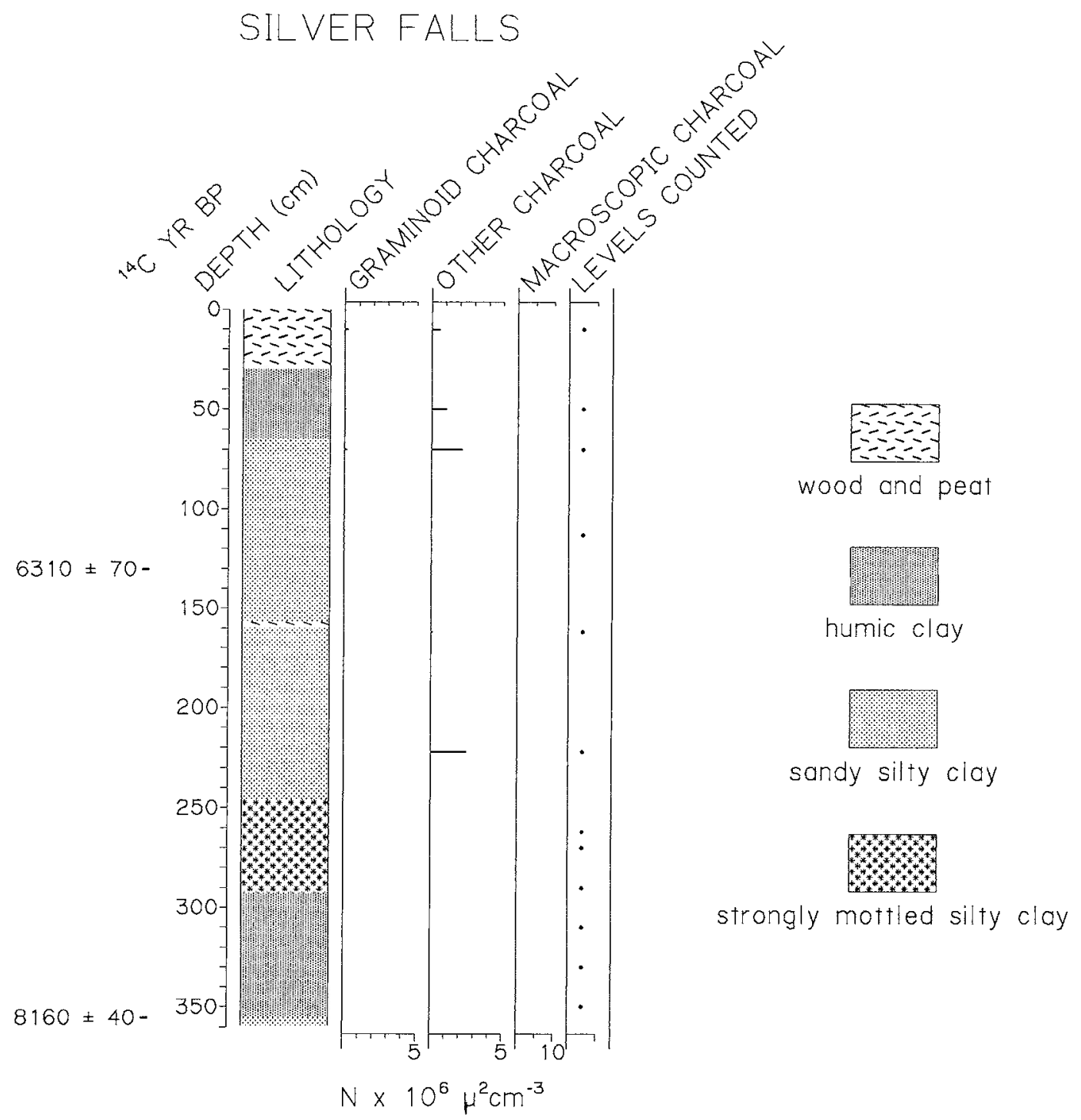

Figure 7. Charcoal stratigraphy from a bog at $169 \mathrm{~m}$ elevation on the Silver Falls Ranch on the north side of Kaua'i.

stratigraphically reversed, but the lower of the two could be contaminated somehow by material from above, or the upper by redeposited material eroding elsewhere in the swamp. Either is possible. The presence of a trace of charcoal around the level dated to $3800 \pm 40 \mathrm{yr}$ B.P. is intriguing, because this is the date of the prehuman charcoal peak at Māhā'ulepū. In any case, it is apparent that charcoal is otherwise very scarce at this site in the late Pleistocene and throughout the Holocene.

\section{Alaka'i Swamp}

The Kilohana region of Alaka'i Swamp (not to be confused with Kilohana Crater elsewhere on the island, see earlier in Results) is an open grass-sedge bog area of northwestern Kaua'i at ca. $1220 \mathrm{~m}$ (Figure 1). The vicinity 


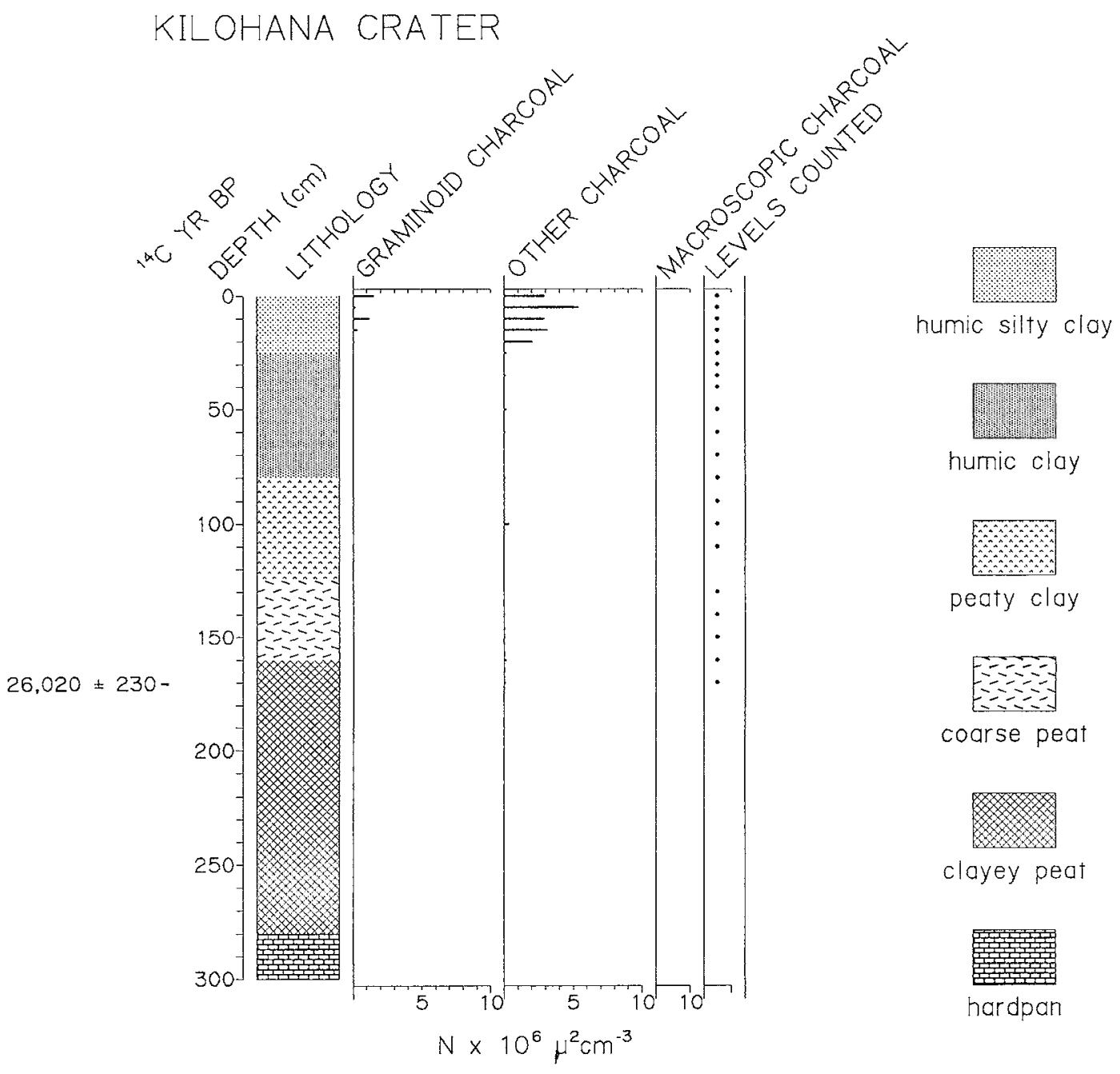

Figure 8. Charcoal stratigraphy from the swamp forest on the floor of Kilohana Crater at $243 \mathrm{~m}$ elevation in the interior of Kaua'i.

was an important coring site for the palynological studies of Selling (1948), which unfortunately predated the radiocarbon method. Subsequently, we have dated a core from approximately the same location (Burney 2002) with a basal age of $15,100 \pm 80 \mathrm{yr}$ B.P. $(18,525-17,623 \mathrm{cal}$ yr B.P.), and a date of $5000 \pm 50$ yr в.P. $(5895-5615$ cal yr в.P.) from $70 \mathrm{~cm}$ below surface.

No substantial amount of charcoal appears in this core at any level examined. Samples were processed and counted at $15-\mathrm{cm}$ intervals, but no diagram was prepared because only a few very small particles were detected at any level and none at most levels. Both Holocene and late Pleistocene sediments are essentially charcoal-free.

\section{CONCLUSIONS}

Three interior sites contained sediments deposited in the late Pleistocene. None of these sediments contains more than a trace of very small charcoal particles. Fire occurrence may have been low at that time as a result of even less lightning activity than today on Kaua'i. 


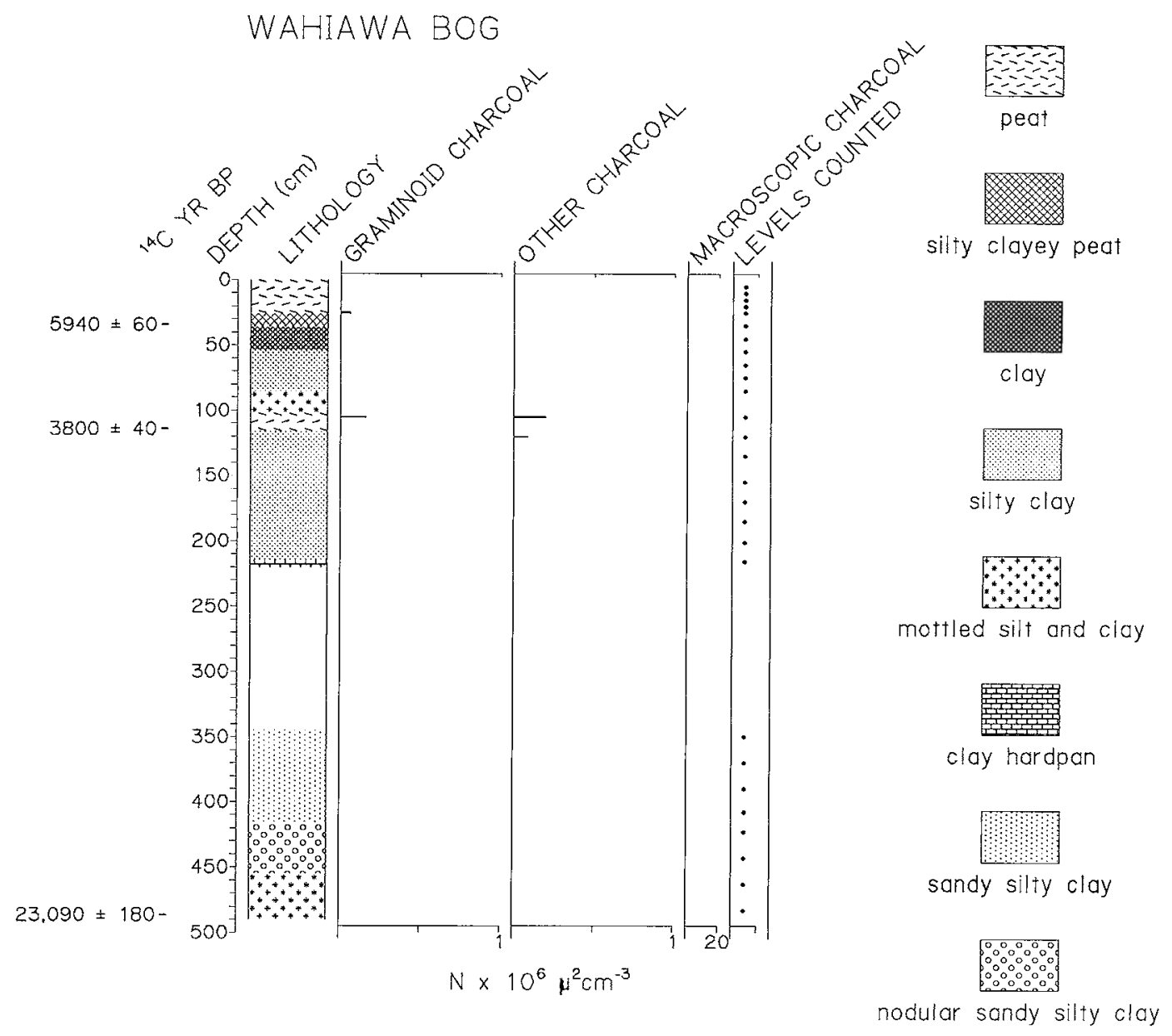

Figure 9. Charcoal stratigraphy from Wahiawā Bog at $665 \mathrm{~m}$ in the interior of Kaua $i$. White space in the lithology diagram indicates a gap in core recovery due to the presence of an indurated layer.

The early Holocene was a time of low fire occurrence as well, although more charcoal was recorded at times on both coasts and in the interior than in the Pleistocene sediments from these sites. By contrast, the charcoal record from Flat Top Bog on the flank of Haleakalā Volcano on Maui (Burney et al. 1995) shows early and mid-Holocene charcoal values that were quite high, probably associated with the activity of the volcano. The sudden increase of charcoal at three or more Kaua'i sites (Māhā'ulepü, Limahuli, Wahiawā, and perhaps Silver Falls) around 3800 yr в.P. (4000-4300 cal yr в.P.), followed by a decline to low background values, is intriguing. A multidecadal drought could ex- plain the occurrence of fires at that time, especially if combined with an increase in dry lightning occurrence. Although an extreme drought event, perhaps lasting three centuries, is believed to have caused the collapse of Mesopotamian civilization at precisely that time (reviewed in deMenocal 2001), it is not known whether similar conditions prevailed in the mid-Pacific. Pollen and sedimentological evidence from Māhā'ulepū (Burney et al. 2001) is also consistent with drought conditions at that time.

Charcoal evidence for human arrival confirms that people were widespread in the Kaua'i lowlands, including the dry leeward valleys, by ca. A.D. 1100 . Evidence that hu- 
mans were at Limahuli on the north coast ca. $500 \mathrm{yr}$ earlier is equivocal. The pattern of initial peaking of presumably anthropogenic charcoal particles, with a plateau of high charcoal values for a few centuries, followed by a drastic decline until European times is documented here from Māhāuulepū, Limahuli, Alekoko, and Kekupua. Interior sites show that charcoal, and therefore humancaused burning, was not prevalent in the higher interior areas in prehistoric Polynesian times, but European-period fires, probably from historically documented activities such as forest clearance and sugarcane burning, are clearly registered near the top of some cores. Flat Top Bog in the high interior of Maui shows the same pattern, with no discernible Polynesian charcoal signal but a substantial rise after European-introduced pollen types appear in the sediments (Burney et al. 1995).

Perhaps the Polynesian land-management strategy in prehistoric times was to clear lowland areas with fire, but it may be that settlement was too dense in many low areas by ca. A.D. 1600 or before to allow much continued biomass burning. Macrofossil and pollen data from Māhā'ulepū (Burney et al. 2001) show that some indigenous trees were still present at the site about the time of European arrival or just before (although none is present today), but it is not known how much actual forest remained or to what extent fire was employed as a landscape-management tool at this late stage in prehistoric agricultural development of the lowlands.

As for the interior, it appears from the charcoal signals from Silver Falls and Kilohana Crater that elevations up to ca. $300 \mathrm{~m}$ were occupied in Polynesian times, but higher sites such as Wahiawā Bog at $665 \mathrm{~m}$ and Alaka'i Swamp at $1220 \mathrm{~m}$ (and Flat Top Bog on Maui at $2270 \mathrm{~m}$ [Burney et al. 1995]) either were not heavily settled by humans or else were settled without much biomass burning. Substantial charcoal at Limahuli in early Polynesian times (or just before) suggests that coastal windward areas were subject to burning despite the high rainfall. The unlikelihood of prehuman fires under such wet conditions with no lengthy dry season (see Burney 1996, 1999 for a discussion of a related situation in the rain forests of Mada- gascar) makes it more plausible that the charcoal plateau initiated at Limahuli at ca. $1470 \mathrm{yr}$ в.P. is anthropogenic. The dating of this event is problematic, however, and the date from bulk sediments suggests that the peak could be even older (1780 yr в.P.). If these dates are discounted due to the evidence for tsunami disturbance and sediment mixing, then no evidence for humans on Kaua $i$ presented here predates the beginning of the second millennium A.D. This is close to the estimate of Athens (1997) for late human arrival in the Hawaiian Islands (ca. A.D. 800).

What is clearly needed to further elucidate the fire history of Kaua' $i$ and make confident comparisons with dated evidence for last occurrence of extinct organisms is a sedimentary record from a site with fine-scale (e.g., decadal to annual) resolution of the Holocene. To our knowledge, such a site has not been found so far.

\section{ACKNOWLEDGMENTS}

Coring efforts were assisted by Adam Asquith, Alec Burney, Reginald Gage II, Don Heacock, Helen James, Pila and Dolly Kikuchi, Kristina Kikuchi-Palenapa, Lorrin Mano'i, Ka'ohulani McGuire, Cameron McNeil, Bob Nishek, Storrs Olson, Mary L. O'Rourke, and Ed Sills. Thanks also to the landowners, public and private, who permitted us to work on their property. $\mathrm{La}$ France Kapaka and Nancy McMahon assisted with official permissions.

\section{Literature Cited}

Athens, J. S. 1997. Hawaiian native lowland vegetation in prehistory. Pages 248-270 in P. V. Kirch and T. L. Hunt, eds. Historical ecology in the Pacific Islands. Yale University Press, New Haven, Connecticut.

Beggerly, P. E. P. 1990. Kahana Valley, Hawaii, a geomorphic artifact. Ph.D. diss., University of Hawai'i at Mānoa, Honolulu.

Burney, D. A. 1987. Late Quaternary stratigraphic charcoal records from Madagascar. Quat. Res. 28:274-280. . 1993. Late Holocene environmental 
changes in arid southwestern Madagascar. Quat. Res. 40:98-106.

1996. Climate change and fire ecology as factors in the Quaternary biogeography of Madagascar. Pages 49-58 in W. Lourenço, ed. Biogeographie de Madagascar. ORSTOM, Paris.

. 1999. Rates, patterns, and processes of landscape transformation and extinction in Madagascar. Pages 145-164 in R. D. E. MacPhee, ed. Extinctions in near time: Causes, contexts, and consequences. Plenum/Kluwer, New York.

- 2002. Late Quaternary chronology and stratigraphy of twelve sites on Kaua'i. Radiocarbon 44:13-44.

Burney, D. A., L. P. Burney, and R. D. E. MacPhee. 1994. Holocene charcoal stratigraphy from Laguna Tortuguero, Puerto Rico, and the timing of human arrival on the island. J. Archaeol. Sci. 21:273-281.

Burney, D. A., R. V. DeCandido, L. P. Burney, F. N. Kostel-Hughes, T. W. Stafford Jr., and H. F. James. 1995. A Holocene record of climate change, fire ecology and human activity from montane Flat Top Bog, Maui. J. Paleolimnol. 13:209-217.

Burney, D. A., H. F. James, L. P. Burney, S. L. Olson, W. Kikuchi, W. L. Wagner, $M$. Burney, D. McCloskey, D. Kikuchi, F. V. Grady, R. Gage, and R. Nishek. 2001. Fossil evidence for a diverse biota from Kaua' $i$ and its transformation since human arrival. Ecol. Monogr. 71:615-641.

Ching, F. K. W., P. B. Griffin, W. K. Kikuchi, W. A. Albrecht, J. C. Belshé, and C. Stauder. 1973. The archaeology of Puna, Kaua'i. Archaeological Research Center Hawaii, Lìhu'e, Kaua'i.

Clark, J. S. 1988. Particle motion and the theory of charcoal analysis: Source area, transport, deposition, and sampling. Quat. Res. 30:67-80.

deMenocal, P. B. 2001. Cultural responses to climate change during the late Holocene. Science (Washington, D.C.) 292:667-673.

Flannery, Tim. 1994. The future eaters. George Braziller, New York.

Grayson, D. K. 2001. The archaeological record of human impacts on animal populations. J. World Prehist. 13:1-68.

Hotchkiss, S. C. 1998. Quaternary vegetation and climate of Hawai'i. Ph.D. diss., University of Minnesota, St. Paul.

Kikuchi, W. K. 1976. Prehistoric Hawaiian fishponds. Science (Washington, D.C.) 193:295-299.

Kirch, P. V. 1985. Feathered gods and fishhooks. University of Hawai'i Press, Honolulu.

Martin, P. S., and D. W. Steadman. 1999. Prehistoric extinctions on islands and continents. Pages 17-55 in R. D. E. MacPhee, ed. Extinctions in near time: Causes, contexts, and consequences. Plenum/Kluwer, New York.

Masse, W. B., and H. D. Tuggle. 1998. The date of Hawaiian colonization. Pages 229235 in C. M. Stevenson, G. Lee, and F. J. Morin, eds. Easter Island in Pacific context: South Seas symposium: Proceedings of the 4th International Conference on Easter Island and East Polynesia. Easter Island Foundation Occasional Paper 4. Bearsville and Cloud Mountain Presses, Los Osos, California.

Olson, S. L., and H. F. James. 1982. Fossil birds from the Hawaiian Islands: Evidence for wholesale extinction by man before Western contact. Science (Washington, D.C.) 217:633-635.

Paterson, W. A., K. J. Edwards, and D. J. MacGuire. 1987. Microscopic charcoal as a fossil indicator of fire. Quat. Sci. Rev. 6:3-23.

Selling, O. 1948. Studies in Hawaiian pollen statistics: Part III. On the Late Quaternary history of the Hawaiian vegetation. Bernice P. Bishop Mus. Spec. Publ. 39.

Stuiver, M., P. J. Reimer, E. Bard, J. W. Beck, G. S. Burr, K. A. Hughen, B. Kromer, F. G. McCormac, J. v. d. Plicht, and M. Spurk. 1998. INTCAL98 ${ }^{14} \mathrm{C}$. Radiocarbon 40:1041-1083.

Swain, A. M. 1973. A history of fire and vegetation in north-eastern Minnesota, as recorded in lake sediments. Quat. Res. $3: 383-396$. 